\title{
BATALHAS DE CONFETE E CORETOS CARNAVALESCOS \\ O DESENHO DE UMA PAISAGEM EFÊMERA \\ NO CARNAVAL CARIOCA NAS DÉCADAS DE 1930 A 1950
}

Helenise Guimarães (UFRJ)

O artigo analisa práticas socioculturais e o cenário artístico que redefiniu o processo de ornamentação carnavalesca na cidade do Rio de Janeiro entre as décadas de 1930 e 1950, período marcado pela descentralização do carnaval carioca devido a momentâneo esvaziamento dessa festa popular no Centro urbano da cidade. As batalhas de confete e os coretos carnavalescos, foco deste artigo, sobressaíam na paisagem carioca, sendo assim considerados elementos de destaque, tanto por suas características plásticas como pelo forte simbolismo que veiculavam, sobretudo aqueles inspirados em nossa identidade nacional. Seja pela forma ou pela ideologia nelas representadas, foram artistas e foliões os responsáveis diretos por essas práticas que, em curto espaço de tempo, encontraram na mídia e no próprio poder público importantes agentes que não apenas apoiaram, mas também vieram legitimar o uso de ornamentações carnavalescas.

DECORAÇÃO, CARNAVAL, PAISAGEM, RIO DEJANEIRO, CORETO.

GUIMARÃES, Helenise. Batalhas de confete e coretos carnavalescos: o desenho de uma paisagem efêmera no carnaval carioca nas décadas de 1930 a 1950 . Textos escolhidos de cultura e arte populares, Rio de Janeiro, v.8, n.2, p. 259-272, nov.. 2011. 
1. O coreto, em sua definição mais simples, consiste num pequeno paviIhão, construído em alvenaria com estrutura de ferro, tendo por finalidade ornamentar praças públicas e eventualmente servir para abrigar bandas de música e outros eventos culturais.

2. Para aprofundar o entendimento da questão espaço/poder no carnaval, sua implicações históricas, políticas, culturais e uma abordagem da questão da geografia carnavalesca na cidade do Rio de Janeiro no século XIX, ver Ferreira, 2005.

3. O Globo, Rio de Janeiro, 14 de fevereiro de 1928.

4. Eneida de Moraes (1987) conta que a primeira grande e célebre batalha de confete do Rio de Janeiro foi organizada pela Gazeta de Notícias em 1907, imitando a batalha de flores que se realizava no carnaval europeu. Em substituição às flores, muito caras, foi usado confete, e seu itinerário compreendia a Avenida Beira-Mar, entre o quiosque mourisco e a estátua do Almirante Tamandaré. Para participar, deviam tanto os pedestres quanto os carros pagar somas que variavam conforme a apresentação, mesmo aqueles que não concorressem aos prêmios. As batalhas se transformariam em gran-
O carnaval carioca se apresenta como vasto campo para pesquisas, reflexões e análises, mas, sobretudo, nos propõe manifestações que são descortinadas quase ao acaso de nossas pesquisas e em dado momento aguçam nossa curiosidade, pois ainda aguardam ter seus fatos contados com a importância atribuída àqueles que nos revelam a trajetória das escolas de samba. Acompanhando a história das decorações urbanas, descobrimos tema instigante: a batalha pelos espaços de poder da festa carnavalesca, batalha que não foi travada pelas instituições oficiais, mas por iniciativa de moradores anônimos ainda no século XIX, e que reencontraremos nas ruas dos subúrbios e bairros nobres da cidade nas primeiras décadas do século XX. Como afirma Ferreira (2005), a cidade deixaria de ser o grande palco do entrudo/ carnaval para que alguns locais se definissem como menos ou mais carnavalescos do que outros, e, para tanto, as decorações desses locais com arcos triunfais, bandeira, festões de flores, entre outros artifícios para recepcionar os préstitos, "passam a ser as principais armas na batalha travada entre as ruas para serem incluídas na nova geografia carnavalesca da cidade". É nesse sentido que abordaremos, ainda que brevemente, as articulações que engendraram batalhas de confete e construções de coretos $^{1}$ artísticos em logradouros distantes do Centro da cidade, como busca do espaço/poder que definiriam novos lugares para o carnaval. ${ }^{2}$

A primeira tentativa oficial de decoração de rua, incentivada pela Prefeitura do Rio de Janeiro em 1928, buscava com a ornamentação e iluminação da Avenida Rio Branco trazer uma novidade que resgatasse a combalida centralidade do carnaval carioca. Em iniciativa inédita contratava-se Luis Carlos Peixoto de Castro - artista e cenógrafo consagrado pela crítica como "hábil desenhista, um caricaturista e decorador de sentimento moderno, sentindo além disso, a alma de nosso povo"3 - com a missão de fazer com que o Rio de Janeiro recebesse, "a exemplo de Buenos Aires, em nossas principais avenidas, uma ornamentação artística e iluminação especial que daria maior realce aos festejos" (FERREIRA, 2005). Os resultados não foram satisfatórios, a não ser pela iluminação, que teve uma boa receptividade pelo público, ao contrário das figuras bizarras da decoração, que determinaram que o Centro da cidade só viesse a receber nova ornamentação na década seguinte. 


\section{NAS BATALHAS DE CONFETE, DONA ZULMIRA REINAVA SOBERANA!}

Prática existente desde 1888, a batalha das flores já vinha sendo gradativamente substituída desde 1906 pelas bataIhas de confete organizadas pela Gazeta de Notícias que traziam para a recém-inaugurada Avenida Rio Branco o gosto pelas decorações. Importadas do carnaval francês e muitas vezes confundidas com o corso, evento típico das elites, essas alegres batalhas não entraram em decadência ao final dos anos 30 como alguns autores afirmariam. Tanto elas quanto os corsos migrariam para os bailes populares dos subúrbios, a ponto de quase eclipsar o carnaval do Centro da cidade. Acompanharam esses desfiles competições que adornaram ruas inteiras, nas fachadas de casas habilmente ornamentadas pelos mesmos técnicos dos préstitos carnavalescos, que descobrem por sua vez marco urbano de importância singular: o coreto.

Distantes do Centro da cidade, os bairros organizavam bailes populares chamados de batalhas de confete, ${ }^{4} \mathrm{e}$, semelhante às comissões de festejos do século XIX, também faziam publicar nos jornais o convite aos grupos carnavalescos. A disseminação do carnaval pelos bairros e subúrbios ao mesmo tempo em que comprovava a expansão da festa, contribuiu para seu esvaziamento no Centro da cidade. Segundo Araújo (1991), as mais célebres batalhas de confete foram as das ruas Dona Zulmira, Felipe Camarão, Avenida 28 de Setembro, em Vila Isabel, e Dona Luzia e N. S. das Graças, em Ramos. A grande quantidade de ruas que promoviam as batalhas nos anos 20 comprova que a luta pelos espaços carnavalescos do Centro teria que apresentar elementos que fizessem os grupos não só retomarem o caminho do Centro, mas ali fixarem suas principais disputas. Para a divulgação de tantos eventos simultâneos, muito contribuiria a imprensa, como, aliás, já se tornara tradicional em sua participação como promotora de concursos e aliada dos foliões.

Antecedendo os dias de carnaval, em janeiro anunciavam-se várias batalhas de confete. ${ }^{5}$ Destacava-se dentre todas a mais famosa, chamada de "Rainha das Batalhas" realizada na Rua D.Zulmira, no Maracanã. ${ }^{6}$ Esses eventos apresentam o diálogo entre os diversos grupos sociais envolvidos em sua execução, mantendo o espírito competitivo tanto das festas populares quanto daquelas promovidas pelas elites. Compondo o cenário dessas batalhas, projetavam-se "coretos artísticos", 7 que abrigariam as comissões julgadoras, as bandas de mú- des bailes populares realizados em bairros e subúrbios da cidade, sendo que tanto a Gazeta quanto o Centro dos Cronistas Carnavalescos continuariam a organizá-las até a década de 1930.

5. No Largo do Machado, na Rua D. Anna Nery, trecho compreendido entre o Jockey Club e a Estação do Riachuelo, na Rua Barão de Ubá, na Avenida Henrique Valadares, estendendo-se pela Avenida Gomes Freire e Praça Vieira Souto, na Rua Abolição, no Engenho de Dentro, no Largo dos Pilares, nas Ruas Carolina Reyder e Emilia Guimarães, no Catumbi, na Rua São Luis Gonzaga, entre o Campo de São Cristóvão e a Travessa da Liberdade, na Rua Torres Homem, entre a Visconde de Abaeté e a Silva Pinto, entre muitas outras.

6. Essa rua mantém o nome ainda hoje.

7. Os coretos artísticos, também chamados de coretos alegóricos e coretos carnavalescos, como será visto, ganham status de expressão carnavalesca e passam a ser objeto de concursos e premiações pelos jornais, constituindo capítulo à parte na questão das decorações urbanas. 
sica e os convidados mais seletos. Esse processo implicava a contratação de artistas, cenógrafos e técnicos eletricistas, bem como a ativa participação dos moradores desses logradouros.

Os concursos realizados na "Rainha das Batalhas" premiavam também as ornamentações, elevando mais ainda a participação dos moradores no evento. Em fevereiro de 1928, o Jornal do Brasil destaca na região do bairro do Maracanã aquela que sobressaía das demais.

O nome desta rua por si só graças a sua desmedida tradição é uma garantia da mais espipocante vitória. Haverá quem por acaso desconheça "a rainha das batalhas", sinônimo perfeito de animação, flores, risos e alegrias estonteante? (...) Os cordões, blocos e ranchos de toda a cidade irão abrilhantar com suas danças e seus cantos originais para fazer jus aos valiosos prêmios. Sem duvida, a batalha da rua D.Zulmira é da pontinha! (Jornal do Brasil, 2 de fevereiro de 1928).

Dessa forma apresentavam-se ricas de detalhes e citações as matérias da imprensa, descrevendo rua por rua como mostra a edição de $O$ Globo de 6 de fevereiro de 1928: As fachadas mais bem ornamentadas: Além da feérica iluminação que fora feita em toda a extensão da rua Dona Zulmira, a iniciativa dos moradores da mesma rua muito concorreu para o brilho da batalha. Era rara a casa que não apresentava sua fachada lindamente ornamentada e iluminada. Cada qual delas estava mais bem cuidada e feita a capricho. No entanto, dentre todas ressaltou a fachada do prédio no 21. Foi ela enfeitada pelo Sr. Pedro Alexandrino de Oliveira, que a fez em homenagem ao proprietário do prédio, Sr. Luiz Almeida. Ao Sr. Alexandrino coube um lindo quadro. Sobressaíram também as ornamentações dos prédios no 15, residência do Sr. Amâncio de Souza, a quem foi entregue uma taça, e a do no 18, onde reside a família Alfredo Pinzarrone, que recebeu uma linda bolsa para senhora.

Por meio dessas batalhas o carnaval se expandiria além das fronteiras do Centro da cidade, estendendo-se a subúrbios distantes, como Santa Cruz, ou atravessando a Baía de Guanabara em direção a Niterói. A prática da ornamentação, porém, não ficaria restrita às ruas ou fachadas das casas. Em 14 de fevereiro de 1928, O Globo anunciava que o Grupo dos Apertados tinha a honra de convidar toda a imprensa carioca e a direção da Companhia Light, para a batalha que teria lugar no dia 18, "no bonde fretado para este fim, que parte da praça Argentina às 7 horas". A Batalha do Bonde de São Januário mostra como os transportes entram como recurso, mobilizando a população e atraindo público e participantes para seus eventos, cujos organizadores, "desejando dar grande brilho a essa festa, já contrataram com a importante casa de flores naturais denominada 'A Pérola' (...) para ornamentação desse bonde, que será dirigido pelo Sr. Ivo Costa".

Estes relatos nos dão ideia do quanto o carnaval atraía já há algum tempo, cada vez mais para longe do Centro, a empolgação do povo, que via a oportunidade de festejar em seus próprios bairros e ruas o período carnavalesco. A competição entre as ruas do Centro transferira-se em outra escala para logradouros mais distantes, concentrando grande quantidade de participantes como na já citada Rua D.Zulmira, que em 1930 homenageou o jornal $O$ Globo, reunindo "mais de 1.000 automóveis e 200 mil pessoas". 
De todos os bairros, incluindo "Copacabana, Botafogo, Laranjeiras, Santa Thereza, Tijuca, para só falar desses lugares, acorre a elite de automóveis para os folguedos que se anunciam", e sem dúvida a descrição de sua ornamentação explica em parte o grande sucesso:

A iluminação em riscos enviesados de lâmpadas possantes, a cargo de habilíssimo engenheiro, que quer guardar seu nome incógnito, foi feérica e tão intensa que teve a impressão de que o giro da terra se houvera modificado e fora dia quando era noite! (O Globo, 21 de fevereiro de 1930).

As premiações chamam a atenção pela variedade e eram distribuídas a critério da Comissão de Festejos da Prefeitura. Grupos e indivíduos fantasiados participavam dessas alegres competições, como mostra o resultado do concurso publicado na mesma edição:

Bloco "Nossa Vida é um segredo", uma taça; Congresso dos Fenianos, uma taça; Bloco dos Fuzileiros em automóvel, uma taça; Sr. Paulo Ferreira Machado, um litro de água de colônia, fantasiado em automóvel; Um lindo pierrot, uma caixa de lança-perfume Rodo; Bloco "Procura Saber", duas jarras; Prêmio de honra aos grupos "Vae haver o diabo", dos Tenentes do Diabo, uma taça; Sra. Silva Pinto, uma linda boneca; Bloco do Jazz, em automóvel, uma taça; Senhorita Irene Sampaio, ricamente fantasiada, um vidro de lança-perfume; Bloco Aprendizes do Amor, uma taça; Bloco "A Turma do sereno", uma taça; Automóvel do C. R. Botafogo, uma caixa de finíssimos sabonetes; Bloco dos Bohemios, em automóvel, um pote de creme; Bloco dos Ciganos, uma "bombonié$r e^{\prime \prime}$; Grupo do Picoli, uma caixa de pó de arroz; Legião dos Promptos, um par de chinelos (O Globo, 21 de fevereiro de 1930).

\section{CORETOS CARNAVALESCOS: MARCOS SIMBÓLICOS SUBURBANOS}

A consolidação dos modelos de ornamentação urbana é o somatório de várias práticas artísticas que se consolidam sobretudo na década de 1940 com a valorização da decoração urbana através do incentivo do poder público. Assim como as batalhas de confete, os coretos artísticos, também chamados coretos alegóricos, mobilizavam grupos de indivíduos na criação e construção de verdadeiros cenários carnavalescos que em 1935 passaram a integrar a programação oficial do carnaval e receber suportes financeiros da prefeitura.

A inclusão do coreto na folia carnavalesca data do século XIX, quando faziam parte dos preparativos para receber os préstitos das grandes sociedades. Sua preparação contava, igualmente, com os cuidados dos moradores, que organizavam eventos e decorações das ruas do Centro da cidade, "principais armas com que cada trecho podia contar em sua 'disputa carnavalesca'" (FERREIRA, 2004). O caráter espetacular dessas produções era detalhadamente descrito pela imprensa, como relata Ferreira (2004, p. 181):

Os enfeites são cada vez mais variados e elaborados e incluem arcos triunfais, bandeiras, festões de flores, estandartes com dísticos, coretos (algumas vezes

suspensos sobre as ruas), palmeiras, desenhos de figuras grotescas, galharde- 
tes, queimas de fogos de bengala, colunas enfeitadas, pirâmides e iluminações a gás entre outras novidades.

O autor também chama atenção para o fato de que a população daqueles quarteirões centrais já se ocupava com a realização de espetáculos carnavalescos, que incluía a contratação de artistas para shows que incorporavam também as decorações dos quarteirões e a folia dos préstitos, o que acentuava "a mistura característica da festa que se constituía nas ruas cariocas" (FERREIRA, 2004, p 181). Do Centro para outros locais essas práticas serão relatadas nos periódicos e analisadas por outros pesquisadores.

Figueiredo (2003 p. 71) ao se referir à pulverização do carnaval ainda no final do século XIX, relata que em 1896 e 1898 "noticiou-se uma grande aglomeração de foliões chic no 'logradouro de bom-tom', como era conhecido o Largo do Machado e em 1897", providenciando a prefeitura "palanques e coretos para a praça principal de Madureira, quando a população suburbana, divertindo-se no próprio bairro, provocou um certo esvaziamento no carnaval da rua do Ouvidor".

Em 1920, a construção dos coretos já implicava aparato cenográfico e a aplicação de um tema, mantendo-se a função original de abrigar comis-

8. Gazeta de Notícias, 17 de fevereiro de 1920. sões julgadoras ou bandas de música, como na estrutura montada no Largo de Madureira, onde foi levantado um "artístico e original coreto representando uma belo nave". ${ }^{8}$ Intensamente iluminado por holofotes giratórios, o coreto representava um navio de guerra e, para que não restassem dúvidas, foi adornado com canhões e abrigou durante o carnaval uma banda de fuzileiros navais. A montagem de vários coretos numa mesma rua possibilitava a multiplicação de temas, acentuando o caráter de "arquitetura efêmera" às construções, capazes de transfigurar ainda que provisoriamente a cidade do Rio de Janeiro "em cenário e palco das representações coletivas de caráter religioso, laico e político em comemoração de algum fato relevante" (CAVALCANTI, 2004, p. 323).

Os coretos artísticos constituem, portanto, uma das primeiras formas organizadas sob modelo envolvendo projeto e temática que nos anos 30 produziram verdadeiras cenografias urbanas nos subúrbios da cidade. A partir da oficialização do carnaval, em 1932, e do concurso organizado pelo jornal A Pátria, a complexidade de sua realização exige não só a manutenção de barracões para execução dos elementos decorativos, mas a participação de cenógrafos, técnicos eletricistas, carpinteiros, pintores, artistas plásticos, floristas e arquitetos.

Se no Centro da cidade qualquer manifestação carnavalesca devia submeter-se às normatizações da prefeitura, a execução dos coretos suburbanos apresentava caráter mais liberal, porém não menos competitivo. Constituíam verdadeiros marcos simbólicos de cada logradouro no período carnavalesco, mobilizando não só os profissionais, mas também os moradores dos bairros interessados na modernização do carnaval. Dessa forma um segmento da população tomava para si o poder de instalar sua própria festa carnavalesca, poder que Ferreira (2005, p. 323) aponta, afirmando que 
quando uma dada sociedade determina que essa ou aquela festa é Carnaval, seu objetivo é instaurar um espaço de disputa específico e privilegiado no qual a ocupação das ruas se beneficia da ideia de liberdade promovida por uma festa classificada como "sem limites", com um espaço-tempo em que "tudo pode acontecer".

Enquanto manifestações artísticas, os coretos não foram excluídos do movimento de nacionalização do carnaval, enfatizando a escolha de temas nacionais com esmeradas descrições de seus enredos publicadas nos jornais. Embora nossa intenção seja apenas incluí-los no contexto das ornamentações urbanas, tendo em vista que merecem estudos mais amplos no que se refere a sua inserção na história da cidade, consideramos relevante colocar ainda que brevemente algumas descrições encontradas que nos dão ideia de como eram desenvolvidos os temas e sua disposição no espaço urbano.

O coreto de Bento Ribeiro, de 1934, cujo enredo escolhido foi "Nossa Terra... Nossa Gente", de autoria do cenógrafo Sylvio Silva, compreendia o espaço que ia "da Rua Divisória até a Estrada de Queimado, em uma extensão de 50 metros por 14 de largura e 22 metros de altura" e dividia-se em duas partes, subdivididas por sua vez em várias fases que ilustravam períodos da história nacional:

1aㅡ Parte: / 1a Fase: Vemos a figura de Pedro Álvares Cabral e seu séquito, pisando a terra de Santa Cruz, ao lado oposto, em uma rica paisagem está nosso gentio e nossa raça. / 2a Fase: As riquezas do nosso solo ostentadas em arcos de um a outro passeio e na distância de cinco metros entre si, seguros por figuras de guaranis. Riquezas que são representadas por pedras preciosas, flores e frutas exclusivamente de nossa terra. / 3a Fase: Apoteose de nosso querido Brasil. É nesta fase que o coreto em seu ponto central exprime as maiores glórias nacionais. Em primeiro plano gigantescas pirâmides de ouro e prata, erguem-se as figuras simbólicas representadas por guaranis, projetando sobre o universo nossas glórias. / 2a Parte: / $1^{\text {a }}$ Fase: Em uma escadaria de ouro e marfim, flores e perfumes, sobe a república para o futuro que nos espera. Neste templo de arte e beleza, no cimo sobre o cruzeiro a figura augusta da Paz, empunhando o Pavilhão Brasileiro que será iluminado por 2.000 lâmpadas em cores naturais, termina esta apoteose em verdadeiro arco-íris de luz (Jornal do Brasil, 10 de fevereiro de 1934).

A segunda fase era composta de painéis descrevendo "os episódios mais memoráveis de nossa história" entre eles "Sonho de Tiradentes ou Inconfidência Mineira", "Grito do Ypiranga”, "Lei Áurea ou Libertação dos Escravos", "Proclamação da República", "Revolução Vitoriosa". Compunham, ainda, as escadarias, grupos de foliões fantasiados como "guerreiros de época", guardando a República, que repousava sob cúpula de 10 metros de diâmetro. Envolvendo o comércio, a população do bairro e um grupo de profissionais que formavam a equipe de trabalho, o coreto receberia ainda uma festa para sua inauguração oficial. Seguindo esse modelo, vários outros bairros erigiam verdadeiras alegorias fixas que nada deixavam a desejar aos gigantescos carros alegóricos das sociedades que desfilavam nas ruas centrais da cidade.

Um exemplo da grandiosidade dessas produções pode ser visto nos coretos montados em Nilópolis em 1934 e 1935, intitulados "O Mundo Marcha" e "O Nosso Ideal" 
Figura 1: Deslumbrante coreto armado na Praça Paulo de Frontein, em 1934 que foi considerado um relicário de arte

Fonte: Centro de Memória da Baixada Fluminense, http://www.cemobafluminense. com.br/cemobafotos/thumbnails. php?album=2

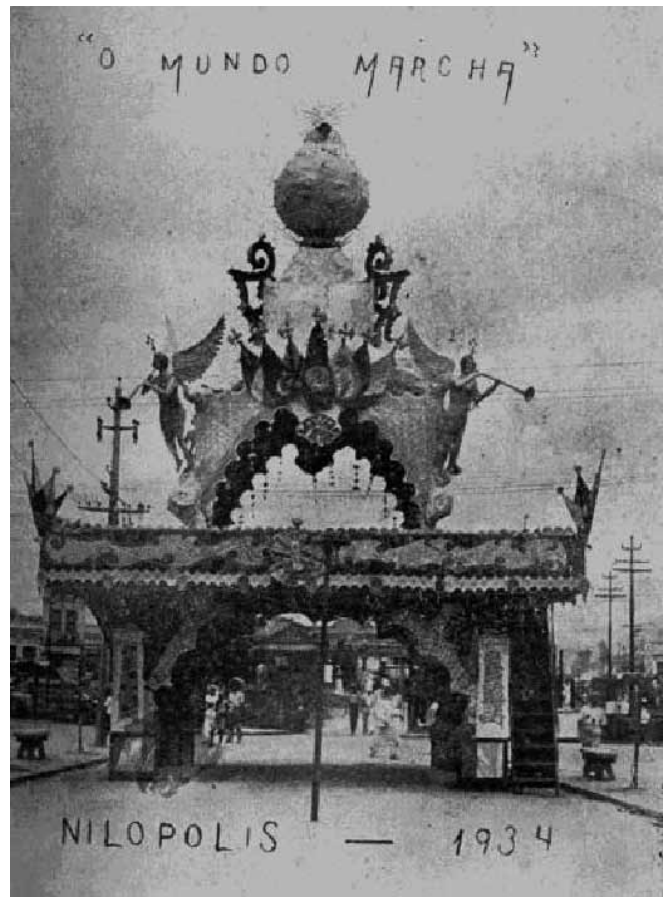

9. Pela extensão desta que é uma das manifestações artísticas mais populares dos subúrbios, e que até os dias de hoje ainda resiste com subsídios da Prefeitura do Rio de Janeiro, que ainda promove concursos, os "Coretos Artísticos" consistem num tema para futuras pesquisas, tendo em vista que o processo de suas criação e execução persistiu com poucas variações. Mesmo não apresentando as mesmas proporções físicas e qualidade visual, consistem em vetores de sociabilidades importantes do carnaval suburbano, articulando moradores, comércio, poder público e agremiações carnavalescas das regiões (figuras 1 e 2), respectivamente, cujas descrições demonstram o impacto que causavam.

Só em 1935 a prefeitura se dispôs a distribuir a "generosa soma de $8: 500 \$ 000$ ", como premiação para os bairros; "trabalhos de arte, gosto e riqueza, trabalhos dispendiosos ate então eram erguidos ante a indiferença dos poderes públicos". $\mathrm{Na}$ administração de Pedro Ernesto e aproveitando "o novo surto de progresso do Carnaval" o chefe do Poder Executivo desdobrava-se em entusiasmo, afirmando que tudo o que fosse feito pelo carnaval era "uma obra de alevantado patriotismo" (Jornal do Brasil, 1ㅇ de março de 1935).

Alguns elementos que compõem a ornamentação do coreto foram compartilhados com as decorações urbanas, que nesse período começam a tornar-se trunfo para os organizadores do carnaval oficial atraírem o público cada vez mais para a região central da cidade.

Ainda pouco estudada, a participação dos coretos no campo da produção artística do carnaval os coloca em evidência que os equipara aos prestigiados desfiles das sociedades, constituindo eles mesmos, em seus bairros, acontecimento gerador de relações sociais vetores da mobilização coletiva. ${ }^{9}$ Da década de 


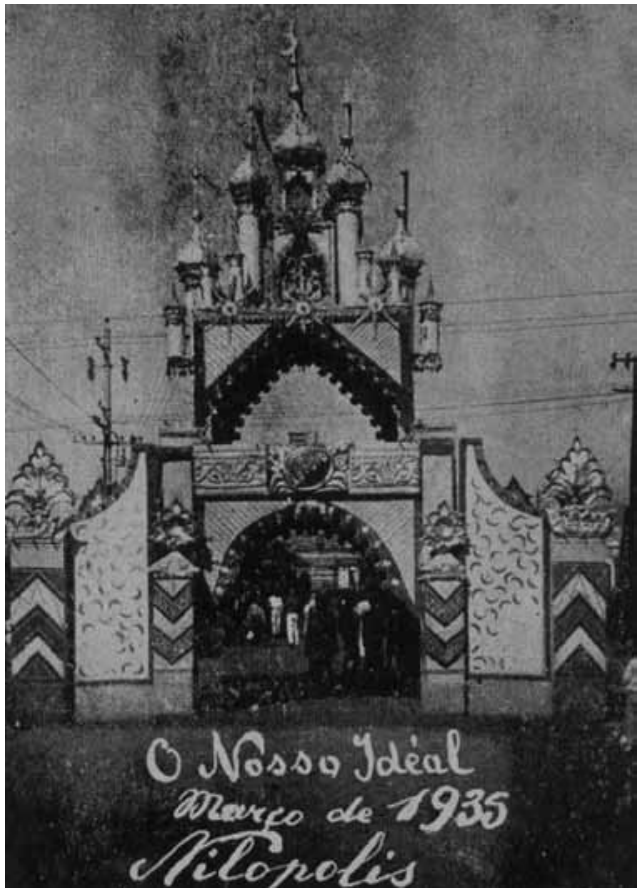

1940 à de 1960, os subúrbios mais distantes buscaram manter a tradição da construção dos coretos contando com a participação dos comércios locais, ainda que a prefeitura não deixasse de regularmente promover os concursos.

As temáticas dos coretos alternariam os motivos nacionalistas com os temas "exóticos", tais como Pagode Chinês, Castelo Árabe, Independência do Brasil, Rapsódia da Alegria e Santos Dumont, para exemplificar aqueles criados pelo artista Américo Belo nos carnavais de Santa Cruz de 1920 a 1957. Guimarãens (1986), ao pesquisar a produção do carnaval desse subúrbio do Rio de Janeiro para a exposição Artesãos do carnaval - carnaval de rua de Santa Cruz, RJ, apresenta breve panorama das produções artísticas que envolviam não só os coretos alegóricos, mas os préstitos idealizados por artistas populares.

A semelhança entre a arquitetura dos coretos e os elementos decorativos que foram adotados nas decorações de rua demonstra que tanto o repertório quanto os conhecimentos técnicos e mesmo os padrões estéticos eram intercambiados entre os artistas e os grupos executores dessas produções. A importância dada à iluminação articulava-se com os elementos simbólicos que aparecem tanto nos coretos quanto nas decorações de onde ainda são erguidos para a festa carnavalesca. Um exemplo é o concurso promovido pela RIOTUR em 2011. Realizado desde 1972, o Concurso de Coretos de Bairros, tem como proposta estimular a população a brincar o carnaval sem se deslocar de seu bairro. No concurso os moradores são os verdadeiros artistas sendo responsáveis pela montagem, decoração e animação dos Coretos. A seleção, realizada por uma Comissão Julgadora, segue os seguintes critérios: criatividade, funcionalidade, conjunto e organização (RIOTUR. visaocarioca.com.br/?p=14923). 
rua: a baiana, o malandro, as figuras tradicionais do carnaval, como pierrôs e colombinas,

10. Segundo Howard S. Becker constituem a arte coletiva todas as atividades necessárias que incluem caracteristicamente "a concepção da ideia para o trabalho, a confecção dos artefatos físicos necessários, a criação de uma linguagem convencional de expressão, o treinamento de pessoal e platéias artísticas no uso de linguagem convencional para criar e experimentar, e a elaboração da mistura necessária desses ingredientes para uma obra ou uma representação particulares". Ele afirma que "todas as artes que conhecemos envolvem redes elaboradas de cooperação" em que existe necessária divisão do trabalho. Tal divisão sempre resulta "de uma definição consensual da situação". No caso dos coretos, das alegorias carnavalescas e das decorações, essa associação cooperativa é fundamental para que se leve a termo qualquer projeto predefinido (BECKER, 1977, $p$. 207).

11. Um exemplo de como a associação dos coretos a seus bairros podia significar estímulo ao progresso de determinados logradouros pode ser acompanhado nos "quatro anos consecutivos em que a progressiva localidade suburbana da Linha Auxiliar, e a aplicação de painéis em madeira compensada com pinturas descritivas de seus enredos. Dois exemplos ilustram bem o padrão alcançado em 1959 e 1960, ambos confeccionados pelo artista João Titio, especializado em coretos carnavalescos.

Em 1959, o Comércio de Santa Cruz apresentou o já tradicional coreto. Esta obra de arte, denominada Folia, media quinze metros de altura e dez de diâmetro. Possuindo quatro lances em forma octogonal, cada lance por sua vez com oito painéis, perfazia no total de trinta e dois painéis decorados com figuras alusivas à festa de Momo. Sua cúpula representava a coroa momesca, com movimento giratório de trezentas lâmpadas. Toda esta estrutura foi erigida dentro de princípios construtivos que permitiam abrigar a comissão julgadora dos blocos, ranchos e sociedades carnavalescas que ali desfilaram (GUIMARÃENS, 1986. p. 8-9).

A outra descrição se refere ao coreto de 1960, que teve por temática "Carnaval em Brasília", constituído de quatro lances de forma octogonal com $15 \mathrm{~m}$ de altura e $10 \mathrm{~m}$ de diâmetro em sua base. Muito semelhante às estruturas que veremos nas decorações da Praça Onze da década de 1950, o coreto é considerado "obra arquitetônica" que

representava as colunas do Palácio da Alvorada, sustentando um gigantesco pandeiro, sobre o qual repousavam oito painéis, focalizando a obra do presidente JK em Brasília. A cúpula era uma baiana ricamente fantasiada nas cores verde e amarela, dotada de movimento. Para iluminar tal estrutura foram gastas mil e duzentas lâmpadas formando um conjunto esfuziante (GUIMARÃENS, 1986. p. 8-9).

Cavalcanti (2004, p. 49), ao analisar a estética dos carros alegóricos das escolas de samba e seu processo de produção, "essa arte carnavalesca, monumental e efêmera, pois que integralmente consumida em seu uso ritual" (CAVALCANTI, 1999), aponta para sua dimensão expressiva e seu caráter coletivo como componentes essenciais para sua compreensão. Fazemos aqui um paralelo com a arte dos coretos alegóricos, cuja diferença marcante está no fato de que, ao contrário dos carros, eles estão fixos num determinado ponto. $O$ coreto artístico, assim como a alegoria das escolas de samba e mesmo os carros decorados das grandes sociedades, apresenta características de transitoriedade e de consumo imediato. Também invocam a participação do público, que é a da "admiração e encanto" (idem, ibidem) e estão inseridos num ciclo de produção anual, como ocorre também com as decorações das ruas da cidade. 
O conceito de "arte coletiva", de Becker (1977), ${ }^{10}$ aproxima o coreto das produções que no mesmo período verificamos nas sociedades, nas escolas de samba e nas produções das ornamentações para batalhas de confete. Outro dado que relaciona os coretos às demais práticas carnavalescas é a articulação de grupos de indivíduos que se organizavam para produzi-los. Essas coalizões, tanto como as dos grupos carnavalescos legalmente constituídos, acabavam for reforçar o reconhecimento dos bairros como produtores organizados dessas práticas. É dessa forma que carnavais "regionais" ficariam conhecidos pela construção de seus coretos, tornando-os uma tradição simbólica daqueles logradouros.

Do mesmo modo que as batalhas de confete, os coretos artísticos reeditavam em seus bairros a formação dos núcleos carnavalescos existentes no Centro, atraindo a população que, assim, circulava entre o Centro e a periferia. Enquanto no Centro da cidade os coretos foram substituídos pela decoração dos espaços públicos, nos subúrbios eles tinham o papel de centralizar a festa. ${ }^{11}$

Em 1936, a Subdiretoria de Turismo inclui no programa do carnaval da cidade o julgamento oficial dos coretos, divulgando previamente o valor das premiações e determinado que as inscrições fossem feitas em oficio dirigido àquela repartição contendo a "localidade do coreto (...) o enredo ou motivos artísticos, dimensões, dia em que será visitado pela comissão, nome do artista e do presidente da comissão organizadora". ${ }^{12}$ O julgamento é tornado público pelos jornais em ata lavrada cuja decisão teria caráter inapelável. Essas normatizações demonstram não só que a competição entre os bairros deixara de ser algo improvisado, mas também reconhecia a união daqueles indivíduos que se articulavam cada vez mais ordenadamente, consolidando um processo de negociações entre os grupos que reproduzia o padrão das competições existentes no Centro da cidade.

A comissão julgadora formada pelo professor Armando Vianna, da Escola de Belas Artes, julgador de desfiles de ranchos pelo Jornal do Brasil, Romeu Arêde, presidente da Associação dos Cronistas Carnavalescos, e pelo Capitão Almir Valente ${ }^{13}$ confere, nesse ano, ao coreto de Campo Grande o primeiro prêmio, reconhecendo

além da majestade de seu conjunto, esplendida divisão de suas massas arquitetônicas muito bem equili- patenteia sua festa máxima" (Jornal do Brasil, 12 de janeiro de 1936).

12. Jornal do Brasil, 12 de janeiro de 1936.

13. Como em todas as comissões julgadoras de manifestações carnavalescas e mesmo as de ornamentação urbana e de salões, os integrantes do corpo de julgadores eram buscados em segmentos diferentes daqueles a que pertenciam as manifestações: teatro, escolas de arte, associações de imprensa, cronistas, membros das forças armadas e do poder público. A exceção a esse costume será observada nas ornamentações urbanas e do Baile de Gala do Theatro Municipal, tendo em vista que, na maioria dos casos, os decoradores pertenciam ao mesmo segmento social - ou à cultura chamada "erudita" - do corpo de julgadores. Quanto maior a interferência do Estado na regulamentação, mais rígido seria o critério de escolha desses júris, que por sua origem e conhecimentos obtinha o aval para avaliar e julgar as competições.

14. Jornal do Brasil, 12 de janeiro de 1936. 
bradas, farta iluminação (...) e fino acabamento (...) sendo visível a sua ascendência sobre os demais. ${ }^{14}$

O carnaval, bem como outras festas e eventos urbanos, configura-se como momento de confraternização entre dois extremos sociais, servindo para atenuar os antagonismos existentes entre grupos diferentes na sociedade. Ao fomentar a associação desses grupos em comissões organizadoras imbuídas do desejo de estabelecer novos espaços para a festa, o carnaval, como observa DaMatta (1983), reinventa não só seu espaço social como cria o espaço de suas próprias regras, as quais estão submetidas às pessoas e à própria cidade. Segundo o autor, o carnaval é capaz de produzir modos alternativos de comportamentos coletivos, pois oferece a oportunidade de serem experimentadas novas formas de relacionamento social que jazem adormecidas.

No caso dessas decorações, verificamos que as casas deixam de ser isoladas, pertencentes a uma família ou indivíduos, para através da ornamentação se transformar em elementos participantes do ritual urbano. No espaço da rua e da praça o coreto tornase então o lócus privilegiado que centraliza o poder e aqueles que o detêm: as comissões julgadoras, os organizadores, as bandas de música. Ao longo de sua evolução, os coretos ganharam importância e autonomia definindo formas regionais de carnaval típicas dos subúrbios que resistem até os dias atuais.

O coreto passa ser suporte de um enredo e expressa uma narrativa, mas continua sendo o local das comissões e bandas. Duplamente simbólico, ele representa um tema e a tradição de um bairro.

Segundo Velloso (2004, p.14), os habitantes de uma cidade criam, a partir de suas vivências, intervenções sensíveis no cotidiano, capazes de "modificar o sentido atribuído aos locais urbanos" cujo "espaço é percebido, portanto, como objeto de uma bataIha simbólica" construída diariamente e que tem o poder de reconceituar seus valores e práticas. Ao focalizar as disputas entre os bairros da cidade do Rio de Janeiro, e o próprio Centro como núcleo de atração das manifestações carnavalescas, a autora afirma que a cidade "não se configura tão somente como materialidade, mas como tecido vivo de relações sociais". ${ }^{19}$ Aqui os grupos ampliam o período fixado para o carnaval, tendo em vista que as batalhas de confete são planejadas e realizadas com antecedência e funcionam de forma metonímica para a festa.

Assim como ocorria com os bailes em recintos fechados, as batalhas de confete prenunciavam os três dias de festa carnavalesca, e para isso os indivíduos se reuniam modificando suas ruas, proporcionando-lhes nova ambientação através das ornamentações e demarcando territórios efêmeros, porém ricos de expressões. Diante da oficialização do carnaval, em 1932, os indivíduos continuarão a reproduzir, com diferentes intensidades, as práticas que caracterizam a pluralidade de uma cultura carnavalesca sempre em movimento, sempre promovendo novos contatos entre as classes sociais.

Essa movimentação constante de informações e práticas permitiu que elementos visuais utilizados nas ornamentações do Centro da cidade fossem transportados para 
os carnavais da Zona Sul, dos subúrbios e até mesmo dos morros, ao mesmo tempo em que faziam o caminho inverso, retornando ao Centro da cidade. Esses elementos plásticos não podem ser vinculados a classes sociais ou a uma determinada cultura, seja ela de elite ou popular, tendo em vista o trânsito que revelam ao aparecer nos cenários dos bailes, na ornamentação dos carros de corso, nos bondes enfeitados, no coreto de Bento Ribeiro e em ruas como a Dona Zulmira.

Como afirma Chartier (1998, p. 55), não é simples identificar um nível cultural ou intelectual considerando apenas objetos e práticas, porém "todas as formas culturais nas quais os historiadores reconhecem a cultura do povo surgem sempre, hoje em dia, como conjuntos mistos", cujos elementos que os constituem são de origens bastante diferenciadas. O autor também se refere à "pluralidade de campos de informação" que o carnaval nos apresenta, quando afirma que o pesquisador não deve entender os vários campos de discurso ou práticas como algo dado a priori, mas sim focalizar as "descontinuidades que fazem com que se designem, se admitam e se avaliem, sob formas diferentes ou contraditórias, consoantes as épocas, os saberes e os atos" (p. 65). Essa descontinuidade está presente nas manifestações carnavalescas cariocas, bem como os vários "saberes" que nele encontramos, seja pelas heranças culturais que a festa congrega, seja pelos conhecimentos técnicos e artísticos que sua elaboração articula. Dessa forma, tanto as ornamentações destinadas aos bailes quanto as de ruas e coretos nos auxiliam na reconstituição de uma poética carnavalesca, de um repertório que é fruto de práticas nascidas em tempos diferentes e de origens distintas.

Para recuperar a centralidade quase perdida, foi necessária a retomada das ruas do Centro resgatando práticas e representações de origens diferentes, agora consolidadas como um carnaval "civilizado". É nesse sentido que a oficialização do carnaval na década de 1930 terá seu papel como novo patamar de representações culturais que se alinharão com os interesses do poder público e dos grupos determinados a conquistar cada vez mais os espaços nobres da cidade e valorizar aqueles que, situados nas adjacências, começavam a atrair novos contingentes de foliões.

O movimento de moradores, artistas e, posteriormente, do poder público só fez ampliar, ano após ano, o raio de influência de uma arte sazonal e efêmera na sociedade carioca por meio de um vigoroso investimento. Essas "batalhas", como mais comumente eram conhecidas, materializaram na cidade uma arquitetura efêmera que contou com a construção de coretos carnavalescos, que além de refletirem o universo competitivo da festa urbana, também revelavam as múltiplas trajetórias de grupos que queriam transformar a capital carioca num palco de folias, em que o colorido, as multiformas, a pluralidade de sentidos, as divergentes relações temporais, os ideários e os estranhamentos geográficos consubstanciavam-se numa paisagem que só e, sobretudo uma manifestação popular como o carnaval seria capaz de engendrar. 


\section{REFERÊNCIAS BIBLIOGRÁFICAS}

ARAUJO, Hiran. Memória do carnaval. Rio de Janeiro: Prefeitura Municipal da Cidade do Rio de Janeiro/Oficina do Livro, 1991.

BECKER, H. Arte como ação coletiva. In: BECKER, H Uma teoria da ação coletiva. Rio de Janeiro: Zahar, 1977.

CHARTIER, Roger. A história cultural, entre práticas e representações. Lisboa/Rio de Janeiro: Difel/Bertrand Brasil S.A., 1998.

CAVALCANTI. Maria Laura Viveiros de Castro. O rito e o tempo:ensaios sobre o carnaval. Rio de Janeiro: Civilização Brasileira, 1999.

CAVALCANTI, Nireu. A cidade mutante. In CAVALCANTI, NIREU: O Rio de Janeiro setecentista, a vida e construção da cidade, da invasão francesa até a chegada da corte. Rio de Janeiro: Jorge Zahar Ed., 2004.

DA MATTA, Roberto. Carnavais, malandros e heróis, para uma sociologia do dilema brasileiro. Rio de Janeiro: Zahar, 1983.

FERREIRA, Felipe. Inventando carnavais. O surgimento do carnaval carioca no século XIX e outras questões carnavalescas. Rio de Janeiro: Editora UFRJ, 2005. Col.História, Cultura e Ideias, v. 3.

. O Livro de Ouro do carnaval brasileiro. Rio de Janeiro: Ediouro, 2004.

FIGUEIREDO, Guilherme Araújo. A morfologia dos espaços públicos de carnaval no Rio de Janeiro. Dissertação (mestrado em História e Preservação do Patrimônio Cultural). Rio de Janeiro, FRJ/Proarq, 2003.

GUIMARÃENS, Dinah Papi de. Artesãos do carnaval - carnaval de rua de Santa Cruz. Rio de Janeiro: Instituto Nacional do Folclore/Funarte/MinC, 1986.

MORAES, Eneida de. História do carnaval carioca. Rio de Janeiro: Record, 1987.

VELLOSO, Mônica Pimenta. A cultura das ruas no Rio de Janeiro (1920-30) Mediações, linguagens e espaços. Rio de Janeiro: Edições Casa de Rui Barbosa, 2004.

Helenise Guimarães é professora doutora da Escola de Belas Artes-UFRJ, coordenadora dos cursos de História da arte e Conservação e restauração, e vice-diretora da Escola de Belas Artes-UFRJ. 